\title{
Images of Europe
}

Citation for published version (APA):

Hofstede, G. H. (1993). Images of Europe. Universiteit Maastricht. https://doi.org/10.26481/spe.19931001gh

Document status and date:

Published: 01/10/1993

DOI:

10.26481/spe.19931001gh

Document Version:

Publisher's PDF, also known as Version of record

\section{Please check the document version of this publication:}

- A submitted manuscript is the version of the article upon submission and before peer-review. There can be important differences between the submitted version and the official published version of record.

People interested in the research are advised to contact the author for the final version of the publication, or visit the DOI to the publisher's website.

- The final author version and the galley proof are versions of the publication after peer review.

- The final published version features the final layout of the paper including the volume, issue and page numbers.

Link to publication

\footnotetext{
General rights rights.

- You may freely distribute the URL identifying the publication in the public portal. please follow below link for the End User Agreement:

www.umlib.nl/taverne-license

Take down policy

If you believe that this document breaches copyright please contact us at:

repository@maastrichtuniversity.nl

providing details and we will investigate your claim.
}

Copyright and moral rights for the publications made accessible in the public portal are retained by the authors and/or other copyright owners and it is a condition of accessing publications that users recognise and abide by the legal requirements associated with these

- Users may download and print one copy of any publication from the public portal for the purpose of private study or research.

- You may not further distribute the material or use it for any profit-making activity or commercial gain

If the publication is distributed under the terms of Article $25 \mathrm{fa}$ of the Dutch Copyright Act, indicated by the "Taverne" license above, 


\section{Images of Europe}

\section{VALEDICTORY ADDRESS}

delivered on the occasion of his retirement as a Professor of Organizational Anthropology and International Management '

from the Department of Economics and Business Administration of the University of Limburg at Maastricht

on 1st October 1993

by Geert Hofstede 


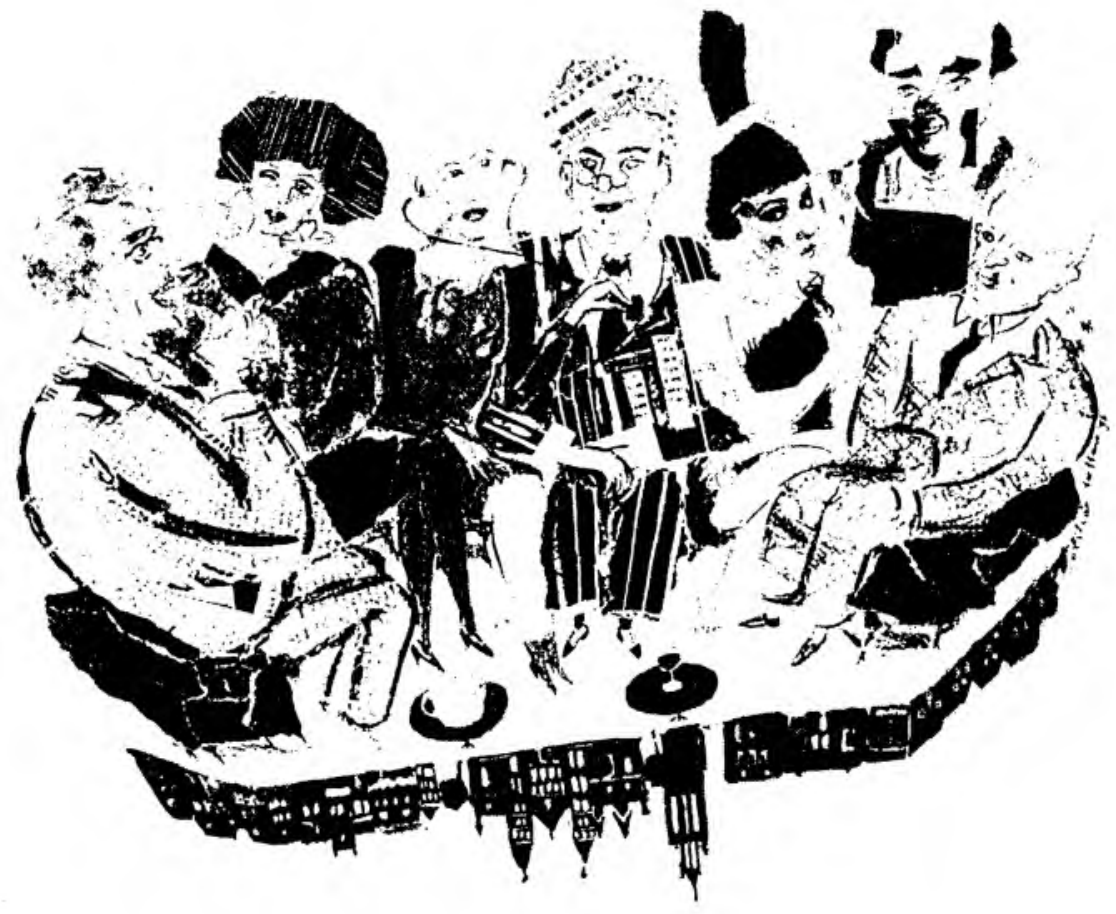




\section{Dear audience,}

Once upon a time, not so long ago, in a pub at the Vrijthof in Maastricht three women and four men were discussing Europe. The women were a historian, a lawyer and a medical doctor. The first three men were a geographer, a politician and an economist. The fourth man was the owner of the pub.

"Europe". said the geographer, "is a peninsula of the Asian continent. It would objectively merit the name 'West Asia' as much as we talk about 'East Asia' for China, Japan and Korea. The population of West Asia is less than that of East or South Asia, but for the time being it is still the wealthiest of the three, although it will probably soon be passed in wealth by East Asia. The land borders between Asia and its Western peninsula are arbitrary: the Urals are not much of a mountain range; if one takes the train from here to China one doesn't meet any real obstacles until near the Mongolian border."

"That is why Central Asian invaders had such an easy passage in past ages", said the historian. "But the distinction between Europe, Asia and Africa existed already at the time of Herodotus, that is the fifth century B.C.

"Does the word 'Europe' mean anything ?" asked the pub-owner.

"The name" said the historian "is supposed to have been derived from a Phoenician word 'ereb" meaning 'darkness' or 'sunset'z. The Phoenicians were the great sailors of the millennium before Christ and they came from the present Lebanon, so for them Europe was in the West, where the sun goes down. Herodotus, by the way, also wondered why three different names were used for Asia, Africa and Europe which were really one continent.";

"Nice to know that Herodotus agreed with me", muttered the geographer. "I would accept Africa as a separate continent, but the distinction between Europe and Asia is irrelevant, geographically and politically. The major border states, Russia and Turkey, cover both continents. I believe the reason why our ancestors treated the West-Asian peninsula as a separate continent and called it 'Europe' was that it allowed them to move the centre of the world this way: it inflated their self-image. The Chinese do the same. They do not refer to their part of the world as East Something: they call their country 'the Middle Empire', the centre of the world. We made Europe the centre; when the American continents were discovered, they were marginalized by calling them 'the New World' allowing us to be the old world. Nonsense of course, all continents are equally old."

"The Old World included Asia and Africa" corrected the historian. "Anyway, Asia had the oldest civilizations. It seems that civilizations have followed the introduction of agriculture with a delay of some millennia. Agriculture has been introduced in Europe by gradual migration from SouthWest to North-East, starting in Anatolia, that is Asia-1. European civilizations have moved the same way, starting with the Greeks, followed by the Romans. After the Romans Europe had little civilization at all for about a thousand years: it really deserved to be called the land of darkness, compared to other parts of the world like the Muslim countries and China."

"But then the Europeans went out to discover the world" interrupted the geographer.

"Civilizations have often expanded by travelling", said the historian. "The new voyages of discovery started in the fifteenth century and soon developed into a competition among several European nations, first the Portuguese and later the Spaniards, the Dutch, the English and the French. Then they gradually developed what you called their inflated self-image of Europe as the 
centre of world civilization and progress. It reached its apex in the nineteenth century when they tried to divide the whole world into European colonies."

"And in the meantime the Europeans fought each other" said the politician, entering the discussion. "Europe has been a very murderous place during these centuries, which doesn't make its claim at civilization too credible. I wonder whether Europe would still hold its leading position in the world if its countries had cooperated more? Now it lost out to North America in the twentieth century, and more recently it is losing out to East Asia."

"I don't like this talking about leading positions and losing out", said the geographer. The world is round and no part of it is more leading than another. Europe's inflated self-image should be over: Europe is just one part of the world and not its centre. To people living in or around the Pacific Basin - like in Hawaii or Samoa - Europe is not a very relevant place at all."

"Present-day Europe", said the politician, "nevertheless got something that no other part of the world has got. I mean the European Community, an attempt at voluntary economic and political integration of a number of nation states without the dominant power of a leading country. As I said these nation states have all fought each other, some quite recently. Shouldn't we be proud of the EC, certainly in this town of Maastricht where the 1991 Treaty was concluded ?"

"I don't know whether there is much to be proud of" - this was the economist. "The European integration hasn't been making much headway since Maastricht. It is moving from one disaster into the other. Also don't forget that the EC only covers half of Europe - 350 million people with some 400 million Europeans still standing by the side."

"It is never easy to make fundamental changes" protested the politician. "It is pilgrim's progress: two steps ahead and one step back. When the step back is taken, people forget the two steps ahead. It is very unlikely that EC countries will evermore go to war against each other. Shouldn't we see the European Community as a laboratory for the world? If one realizes the size of the problems mankind has to cope with: overpopulation, exhaustion of resources, a wise use of nuclear and genetic engineering, national and religious fanaticisms, incurable diseases, there is no other way to survival than international cooperation. If only for that reason, the EC merits our commitment and our pride."

"At one time", said the lawyer, clearing her throat, "I believed the EC meant that Europe would grow to a common legal and judicial system. But what we have learned since is that a written law does not necessarily mean the same thing in different countries. Take the problems in implementing the 1985 Schengen Agreement about the opening of the internal borders and the control of the external borders. Like the new French government not wanting to move ahead with Schengen because of the Dutch way of handling drug addiction. It makes you realize that besides the written laws there are unwritten 'living laws' in the minds of the people that differ from country to country and that you cannot harmonize by formal agreement. Besides, the institutions that have to implement them differ: the German police, for example, does not report to the civil authorities, the burgomasters, like in our country. And even more fundamentally, the mutual roles of the citizens and the authorities differ. There is more mutual trust between police and citizens in the Netherlands than in Belgium. Therefore in our country the police can rely more upon the help of the citizens in a crisis situation, and the citizens upon the police, than in Belgium."

"The mutual roles of patients and doctors are also different from country to country" said the doctor. "A dissertation at the University of Limburg in 1990 studied sickness absences from work in Belgium, Germanv and the Netherlands. Controlling for all kinds of compounding 
factors, time lost from work in Belgium was three percent, in Germany five percent, and in the Netherlands eight per cents: two and a half time as much as in Belgium. I think the decisive cause is the attitude of the medical officers who have to certify these absences. We Dutch doctors are treating our patients more kindly, and give more weight to their opinions. There is no evidence of real differences in health between the countries. Life expectancy at birth is about the same all over the EC, between 74 and 77 years 6 . We see the same patient-oriented attitude in the Dutch position towards euthanasia, and in our treatment of hard drug addicts to which you already referred."

"You are reallpsuggesting that our medical and our legal differences have common roots", said the lawyer:

"And very old roots at that", resumed the historian. Countries have remained separate precisely because there existed fundamental differences in thinking and feeling between them. Why do you think the Belgians revolted against the Dutch in 1830 ? The border between Belgium and the Netherlands revives the border between the Roman Empire and the barbaric Germanic tribes, which has been fixed in its present position in about the fourth century A.D. The other national border close by here, the border between Germany and the Netherlands, follows the division of Charlemagne's empire among his three sons at his death in 814 A.D. Since, the Netherlands have turned towards the sea and the German states have turned inland, which has resulted in quite different mentalities."

"There seem to be as many mentalities as there are countries", reflected the doctor. Take the attribution of the causes of sickness. If they don't feel well, Germans - doctors and patients alike - tend to blame their hearts, French their liver, and Brits their lack of self-control?. No wonder they cannot agree on the EC either."

"Which is a great pity", said the economist with a sigh, "For Europe is an enormous market. It potentially represents a tremendous economic power. Why does economic coordination meet such irrational barriers? With the present recession even the EC can hardly withhold governments from attempting the old pernicious national protectionism again, which can only make the recession worse as everybody should know. And why do the British resist a common Social Charter? And why are the Danes so difficult? And the problems are not only at the government level. Cross-border mergers of private firms and other forms of inter-business cooperation often run into trouble. Germany is the biggest trade partner of the Netherlands and yet several mergers between firms from the two countries have been dramatic failures. And this is only the EC. Include Eastern Europe and the irrationality becomes complete. Apart from being barbaric, the wars in the former Yugoslavia are ruining the economies of those countries for the next half century or more. Why would anybody want to do that ?"

"Yes, it is horrible", said the politician uneasily, "it is going back to the Middle Ages but with modern weapons. But still I think that without the European Community things would be even worse, much worse. And to what extent are we responsible for Eastern Europe? Shouldn't they resolve their own problems first, like we should resolve ours? Some countries like Czechia and Hungary are already setting the example. In a decade or so, they may be ready to join the EC. Maybe the other former communist countries should first bundle their forces in a new common market of their own. Something like a neo-Comecon. That would be in a much better negotiating position than all those unstable old and new countries."

"If I hear you all speak about Europe", said the historian, "you confirm a truth that has existed for twenty-five centuries: Europe is a social construction" 8 . 
"That may be so", said the pub owner. "But to me Europe has become a reality because I am from here. It was real luck that we got the EC Ministers' conference here in December 1991. I don't know what will happen to the Treaty, but everybody in Europe knows the name Maastricht now. Europe may be a social construction, but I feel no longer only a Mestreechter, a Limburger and a Dutch citizen, but also a European."

At this point we will leave our seven friends to their beer, and I will comment on some of the issues they raised.

\section{Mental programming in five dimensions}

The consensus of the discussion was that the way people think, feel, and act in many different kinds of situation is somehow affected by the country they are from rather than by their being European. The country is of course not the only factor: in the discussion it was evident, for example, that among the seven participants the profession of the speaker affected her or his viewpoint and feelings. On top of that people's social class, education, generation, gender, working place and other collective characteristics also influence their thinking, feeling and acting. I have called these influences metaphorically 'collective mental programming'. Maybe 'pre-programming' is an even better term, because the programming is only partial: it is up to the individual what he or she does with it. The seven people in the pub called it 'different mentalities'. A fashionable term in sociology is 'habitus', a word introduced by the Frenchman Pierre Bourdieu?

For an explanation of the country influence on people's habitus we have to turn to social anthropology: the science of the functioning of human societies. Anthropology teaches us that all human societies, both traditional and modern ones, face some of the same basic problems; but the answers differ from one society to the next. What these problems are is a matter of empirical research. It has been one of the main purposes of my own research efforts over the past thirty years:0. Many of you will know that I found four, and later five, universal problems to which people from different countries tend to give different answers. These explain differences in collective behaviour in many different spheres of life: in the family, at school, at work, in politics, and in the cherishing of ideas.

The first question deals with the inequality between people in any society. I expressed this in the term 'Power Distance'. The answers on the inequality questions reach from: "inequality is a normal and desirable thing", which means large Power Distance, to "inequality should be avoided as much as possible", which means small Power Distance.

The second question deals with the relationship between individuals within a society. The answers on this question reach from "everybody for him or herself", which is called Individualism, to "people should remain attached to tight groups throughout life", which is called Collectivism.

The third question deals with the social roles in a society related to being born as a boy or as a girl. The answers on this question reach from "social gender roles should be maximally different" ", which is called Masculinity, to "social gender roles should be maximally overlapping", which is called Femininity. A large difference between gender roles leads to a 'tough' society; a large overlap to a 'tender' society.

The fourth question deals with the level of anxiety in a society when it is confronted with the Unknown. I expressed this in the term 'Uncertainty Avoidance' The answers on this question 
reach from fear, which means strong Uncertainty Avoidance, to curiosity, which means weak Uncertainty Avoidance.

The fifth question deals with the time perspective in a society for the gratification of people's needs. This runs from long, like a lifetime, to short, focussing on gratifying needs 'here and now'. I have labelled the range of answers to this question: Long Term versus Short Term Orientation. Long Term Orientation implies a stress on virtuous living in this world, with Thrift and Persistence as key virtues. Short Term Orientation goes together with a stress on finding the Truth with a capital T: Truth rather than Virtue assures salvation.

In my research I have considered these five questions as dimensions of national mental programmes. For each dimension I have developed a yardstick allowing to quantify, that is express in a number, the position of a country on that dimension relative to other countries. Quantification is a common way of simplifying complex information. Professors do it when they allocate grades to students on the basis of their answers on tests. Consumer organizations do it when they compare the performance of different products. In the case of dominant national mental programming I constructed the numbers for more than fifty countries on the basis of the answers on survey questions by large samples of similar employees from the multinational corporation IBM around 1970.

A key question for any type of quantitative scores is their reliability, that is the extent to which different observers arrive at the same results. The reliability of research results can be determined by independent replications of the research. In social science independent replications are essential to make research respectable.

The most extensive replication of my research has so far been done by Michael Hoppe from North Carolina. His data were collected from alumni of the Salzburg Seminar in Salzburg. Austria. Salzburg Seminar participants are elites, "current and future leaders in their respective countries. They include, among others. Chief Executive Officers of prestigious national and international companies, top-level administrators of national and international governments, diplomats, chancellors and deans of universities or colleges, supreme court justices, and artists "1". Hoppe obtained survey results from more than 1,500 Salzburg alumni from nineteen mainly European countries, in 1984, that is some fourteen years after my research data were collected. His research is therefore really independent from mine.

The differences in mental programmes he found between these elites were quite similar to what I had measured before and, allowing a margin of measurement error in both mine and his data, supported my quantifications. Limitations to the Salzburg sample are its smaller size $(1,500$ versus over 100,000 for the IBM data) and the fact that the selection process of Saizburg participants is not necessarily matched from one country to the next. The respondent groups differ in composition across professions and political affiliations, and for some countries this reduces the comparability of the answers to other countries.

Assuming that many of you have seen enough of my scores, in the remainder of this lecture I will mainly use Hoppe's country scores for differences between national mental programmes. 1 have to limit myself to the first four dimensions, because for the fifth dimension, Long Term Orientation, we have data for five European countries only'2.

While I was working on this lecture Europe was very much in the news, mostly bad news, like the failure of the European Monetary System and the inability to take effective joint action in the former Yugoslavia. At times I regretted the choice of my topic. It is not easy to be reflective while the house is on fire. On the other hand it may be more than ever needed. 


\section{Are Europeans special?}

A first issue is whether Europeans are collectively different from other world citizens. Do they give similar answers to the problems of inequality, individualism, gender roles, and uncertainty?

The diagram is based on data from sixteen European countries: Austria, Belgium, Britain, Denmark, Finland, France, Germany, Greece, Ireland, Italy, Netherlands, Norway, Portuga!, Spain, Sweden and Switzerland; no East-European countries were included. It shows the difference between the highest and the lowest scores on each dimension among the sixteen countries, compared to the maximum difference found in the entire world. The entire world means more than fifty countries.

\section{POWER DISTANCE}

100

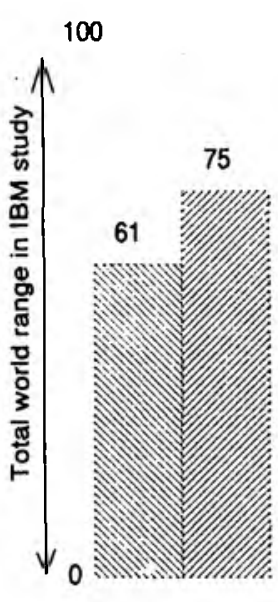

INDIVIDUALISM

98

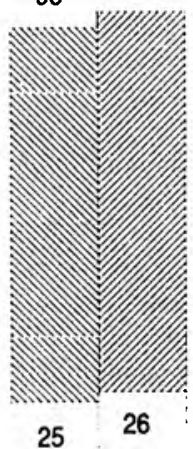

25
MASCUUNITY AVOIDANCE

IBM EMPLOYEES, 1970
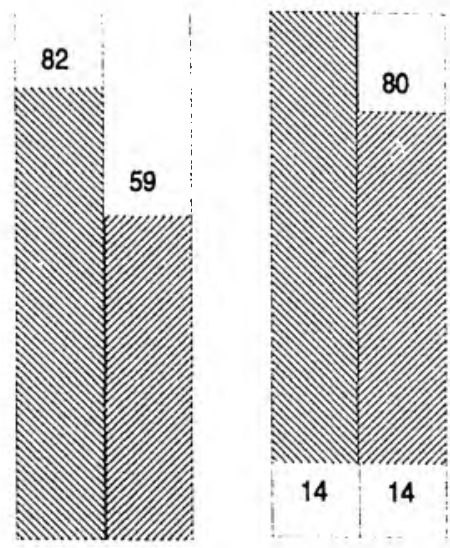

Range of scores for 16 European countries in two studies in per cent of range for total world in IBM study

The diagram shows that for example on Power Distance the scores for these European countries in the 1970 IBM study fell in the lower $61 \%$ of the world range, and in the 1984 elites study they fell in the lower $75 \%$ of the world range. For Individualism the scores fell in the upper 75 $\%$, etcetera. So: in both studies European countries varied strongly in the answers their citizens gave to questions related to the same basic problems of human societies. The extremes not found among these sixteen European countries are very large Power Distances, very low Individualism, that is strong Collectivism, and very strong Masculinity. But the differences are still large enough to consider Europe a small-scale model of the world in terms of variety in mental programming. 


\section{Latin versus Germanic minds}

In the pub discussion the historian said that the border between Belgium and the Netherlands near Maastricht revives the border between the Roman empire and the barbaric Germanic tribes. In fact the inheritance of the Roman empire cuts through the middle of the European Community. On the Latin side we find Belgium, France, Italy, Portugal and Spain, all countries speaking a Romance language, plus Greece; on the Germanic side Britain, Denmark, Germany, Ireland, Luxemburg and the Netherlands, all countries speaking a Germanic language. Although parts of some of the Germanic countries have also been under Rome for some time - like Southern Germany and Britain - the Roman civilization has not settled there. Flanders is the only Germanic-speaking region that acquired a Latin mentality, because it was dominated by Frenchspeaking overlords.

The Roman empire - the first large empire in the heart of Europe - was characterized by a single power centre (implying large power distances) and a uniform system of laws (implying strong avoidance of uncertainty). In this diagram I have plotted the scores on Power Distance and Uncertainty Avoidance for eleven countries from the EC (all except Luxemburg for which I have no data).

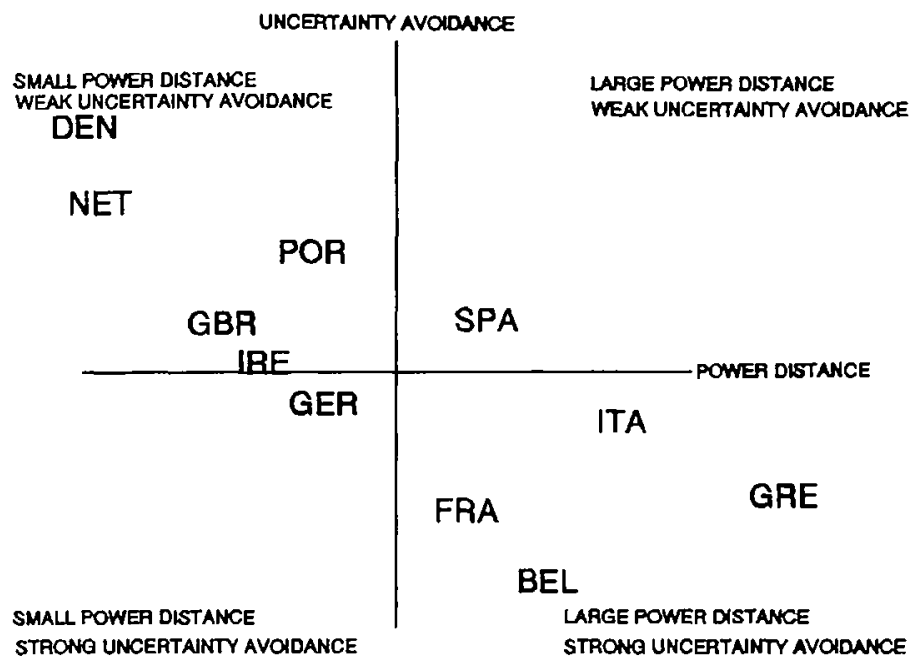

Power Distance versus Uncertainty Avoidance scores for 11 EC countries in the Salzburg Seminar alumni study (Hoppe, 1990)

The diagram is based on Hoppe's Salzburg study of elites in 1984. Power Distance scores are plotted horizontally from left to right, Uncertainty Avoidance scores vertically from top to bottom. In comparison to the 1970 IBM study the 1984 Salzburg study scores are most different for Portugal and Spain: the elites indicate much smaller Power Distances and weaker Uncertainty Avoidance. Spain and Portugal both went from dictatorships to democracies in this period. The Salzburg Seminar is likely to have selected the elites who stood for democracy, not the ones who stood for dictatorship. The IBM data have not selected respondents on this criterium so they were probably more representative of the thinking of the total population. 
The points representing the eleven countries are all close to the top left to bottom right diagonal of the diagram. This means that for EC countries, Power Distance and Uncertainty Avoidance vary together. This is a peculiarity of this group of countries which not necessarily applies to other countries.

The Latin countries present medium to large Power Distances and medium to strong Uncertainty Avoidance, the Germanic countries smaller Power Distances and weak to medium Uncertainty Avoidance. In fact the diagram looks somewhat like the map of Europe, with Greece in the South-East and Denmark and the Netherlands in the North-West, but the plot was not based on geographical data but on mental programmes. The inheritance of the Roman empire survives in the minds of the populations of the Latin countries. The long shadow of Emperor Augustus shows in this diagram. The Germanic countries never knew the same centralization of power, nor a universal system of laws, implying greater equality and tolerance for uncertainty.

On the Germanic side the extreme country is Denmark; this was also the case in the 1970 IBM study. The Danes are characterized by very small Power Distances and very weak Uncertainty Avoidance. This fact explains the hesitation of the Danish voters in ratifying the Maastricht Treaty. The small population of Denmark - 5 million out of 350 million for the whole EC - has a strong sense of equality; thus a referendum on the Treaty was inescapable. The Danish voters are critical about transferring part of their government power to Brussels, which will increase its distance. They are also critical about receiving more EC directives for which they may feel no need.

Surprisingly, Denmark among the twelve EC countries has the best record of application of EC directives in its national legislation. Belgium, on the opposite side of the Power Distance and Uncertainty Avoidance scales has the worst record. The need for, or the rejection of, rules as a function of Uncertainty Avoidance is emotional, not instrumental; so if there is a strong need for rules, this does not mean that the rules established will also be followed. In Denmark the feeling is that rules should only be established when really needed, but then they should also be followed.

In both the IBM and the Salzburg study, Germany occupies a middle position in the diagram with small Power Distance but medium Uncertainty Avoidance. Britain and Ireland are close to Germany in this diagram, but they produced lower scores on both dimensions in the IBM study: they were in between Denmark and the Netherlands. German Uncertainty Avoidance stands for clear rules; because Power Distances are small, indicating a sense of equality, these rules apply irrespective of persons. To Dutch observers in the different cross-border studies I have been involved in, German mental programming is legalistic.

René Olie from our department, jointly with Petra Aler from the Rheinisch-Westfälische Technische Hochschule Aachen, has over the past years studied why German-Dutch mergers of business companies have such a poor success record. In one case of a failed merger the new international corporation, on the advice of a famous consultancy firm, introduced a product based divisional structure. This new structure cut right across the legal structure of the corporation, which still followed national lines. It turned out that the Dutch were able to work within this setup; the Germans were not ${ }^{3}$.

IRIC, the Institute for Research on Intercultural Cooperation of which I have been the founding director, studied cross-border cooperation between the police forces of Belgium, Germany and the Netherlands; for this project IRIC collaborated with METRO, the research institute of the Law department of this University. One difference between Germany on the one side and the Benelux countries on the other is the amount of discretion left to a police officer to report or $n$ 
to report infringements of the law. Both in the Netherlands and in Belgium the 'principle of expediency' applies, which means that the police officer may decide whether or not to report a law infringement. In Germany the 'principle of legality' applies, which means that every law infringement should be reported. The police officer has no discretion in this respect. In practice reporting every infringement is not aiways possible, but this is something German police officers don't like to talk about: to them it would mean confessing that they have acted illegally.

In my 1980 book I have showed that Uncertainty Avoidance is negatively associated with 'citizen competence', that is the extent to which citizens believe they can effectively participate in local political decisions: whether they feel they can get the local political system to move on issues important to them, or whether they feel helpless in front of that system (like the personalities in Kafka's novels) i4. The rank order of the three border countries on Uncertainty Avoidance, both in the 1970 IBM study and in the 1984 Salzburg alumni study, is: Belgium very high, Germany medium, Netherlands lowest. The same order is reflected in the two areas mentioned in the pub discussion: sickness absence and relationship between police and citizens. In both cases Belgium and the Netherlands are far apart, in spite of having been neighbours forever and shaped by the same historical events, sharing a common language, collaborating in the Benelux Union since 1960 , and being indistinguishable to travellers from overseas. I found no other case in the world of two neighbouring countries having so much in common and still showing such differences in their mental programming.

\section{Lone versus together and tender versus tough minds}

In the next diagram I have plotted the scores for the same eleven countries on the two remaining dimensions: Individualism and Masculinity. The diagram is again based on Hoppe's Salzburg study of elites. Individualism scores are plotted vertically from top to bottom, Masculinity scores horizontally from left to right. Again the Salzburg study scores are most different from the IBM scores for Portugal and Spain: the elites from Portugal score more masculine, and those from Spain more individualist and more feminine.

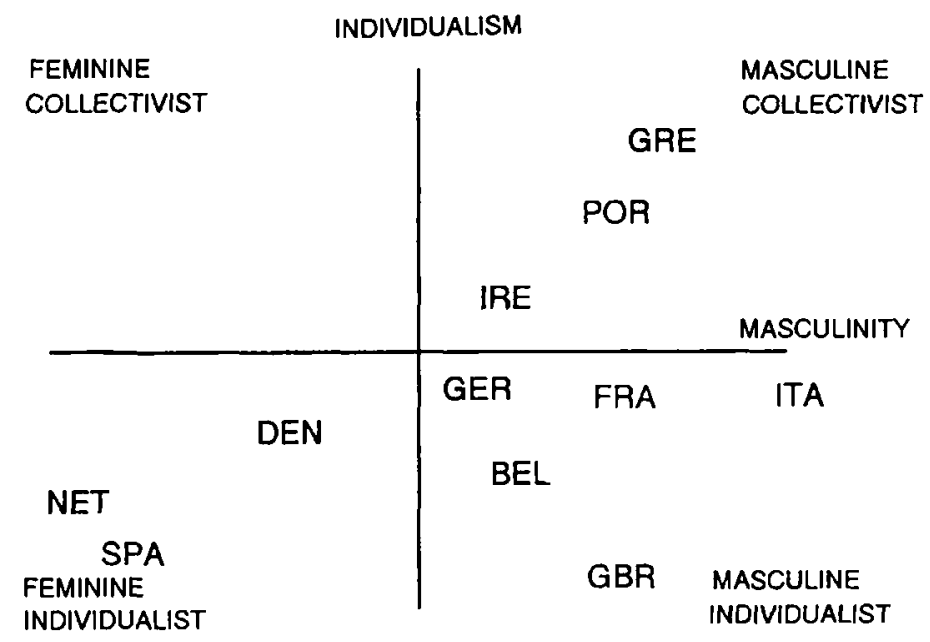

Masculinity versus Individualism scores for 11 EC countries in the Salzburg Seminar alumni study (Hoppe, 1990) 
On Individualism the extreme countries are Britain which scores very individualist in both studies, and Greece which scores collectivist. The problems of the ratification of the Maastricht Treaty by Britain are well known. The Brits - like the Danes - have acquired several exception clauses. The most sensitive issue for Britain is the Social Paragraph. This sets minimum standards for working conditions in the member states. British individualism implies a strong belief in the market, and in Britain this includes the labour market. Working conditions are supposed to be a topic for negotiation between employers and labour unions. Governments should not interfere in this process. The argument that labour, as the weaker party, should be protected by laws does not appeal to the fairly masculine British mentality which leaves little sympathy for anything weak. The twelve year regime of Prime Minister Margaret Thatcher has strongly manifested both individualism and masculinity. It has stressed those individualist values on which Britain differs most from other EC members.

In the case of Greece the EC has hurt itself against Greek nationalism in the recognition of the former Yugoslav state of Macedonia as an independent country. Greece combines strong Uncertainty Avoidance (as we saw in the previous diagram) with Collectivism. Uncertainty Avoidance stands for intolerance of what is different, Collectivism for loyalty to one's own group and hostility to other groups. Collectivism is at the root of ethnic conflicts anywhere in the world. The Greeks have argued that allowing a country to call itself Macedonia represents a threat to Greek sovereignty because Northern Greece is also called Macedonia. Imagine the Dutch refusing Belgium the right to call its North-Eastern province Limburg, because this means a threat to the Dutch province of Limburg which they will probably want to annex. In individualist Netherlands such an argument would be ridiculous, in collectivist Greece it is not.

The Netherlands, both in the Saizburg study and in the IBM study, figures as the most feminine of the EC countries. The Dutch have a strong sympathy for the underdog and the anti-hero which within the EC they share only with the Danes. In this respect they differ from both neigbours Germany and Belgium; the difference shows, among other things, in the tender approach of the Dutch to sickness absence and drug addiction, two topics discussed in my pub story.

On behalf of the EC commission IRIC, my institute, is involved in research on the public acceptance of biotechnology. Biotechnology and genetic engineering are areas of great innovative promise, but they raise questions about ethical acceptability, environmental risks, and the need for government control. Public opinions about biotechnology have been measured within the $\varepsilon C$. and they differ strongly between countries for reasons not evident at first sight. In the first phase of our research we have shown that a combination of Masculinity and large Power Distance characterizes countries in which the population has a 'great expectations, no problems, no nonsense' attitude towards biotechnology. The opposite, Femininity and small Power Distance, characterize countries where expectations are mixed, the awareness of risks is high, and the call for government control is strong. 


\section{Eastern Europe}

The last part of this address will be devoted to Eastern Europe. The classification of countries into East-and West-European was imposed by the former Iron Curtain, but it is historically unfounded. Now that the Curtain has been lifted we can start to look behind it. We find an extremely diverse collection of nations, some with homogeneous and some with heterogeneous populations, some industrially developed and some agrarian, some relatively rich and some extremely poor. The only thing these nations share is the experience of communist rule but this experience has been relatively short, historically spoken: for most of them some forty-five years only.

Communism was an attempt to stop history and to make it obey new rules; to clean people's minds of their historically developed programmes and to re-program them. This was an arrogant claim; an attempt by political leaders to play God. It has bitterly failed. History resumes according to the old rules where it was interrupted.

Now, however, a similar arrogance can be noticed in the claims of those Western economists and politicians who believe that after the failure of communism they can turn the people of the East-European nations into free market capitalists. They don't know history, and they seem to ignore that there is such a thing as collective mental programming.

Communism was closer to the mental programmes of many East-European peoples than is free market capitalism. In the eyes of many people in Eastern Europe, the communist period was not all that bad. To quite a few it was better than anything they had known before. The French anthropologist Emmanuel Todd has argued that the ideology of communism fits the traditional family structures in those countries is. I think he oversimplified; he overlooked other influences, and he did not take account of the fact that only in Russia communism was a native development; in the other East-European countries it was imposed by military force. But at least Todd pointed to a source of mental programmes that politicians cannot change. In my research it shows up as Collectivism. Americans sometimes use the word 'collectivism' for 'state collectivism', as a synonym for 'communism'. This is not what I mean; I use the word in the sense of group collectivism; but the group collectivist mind is also more prone to accept state collectivism.

Free market capitalism presumes an individualist mentality, which is exactly the opposite. Everyone for him- or herself, and the invisible hand of enlightened self-interest will lead us all to the common good. This ideology stems from Adam Smith who was a Scot; it is most actively practiced and preached in the UK arid the USA. No country of continental Western Europe has ever fully embraced it. In my research I have shown a statistical relationship between the degree of Individualism of countries and their national wealth. However, the arrow of causality is not from individualism to wealth, but from wealth to individualism ${ }^{16}$ : a country becomes more individualist after it has increased in wealth, but not necessarily wealthier after it has become more individualist. This means that free market capitalism is more suitable for wealthy countries than for poor ones, and unlikely to make poor countries wealthy as quite a few economists seem to believe.

Relatively well-to-do Eastern European countries are Czechia, Poland, Hungary. Slovenia and Estonia. In these a certain measure of capitalism has the best chances, but it should still be capitalism European style, say German style; not American or British style.

In the poorer East-European countries the demise of communism has not eased the way for capitalism. The only visible alternative to communism in these countries is militant nationalism; 
we can find daily testimonies of it in our newspapers. Like communism, nationalism is based on group collectivism: "It is them or us". Collectivism combined with strong uncertainty avoidance produces an explosive mixture: strong Uncertainty Avoidance stands for intolerance of others, of "What is different, is dangerous". This mixture exists in the case of Greece, but mitigated by the fact that Greece is a relatively prosperous country which therefore undergoes individualist influences.

The Hungarian political philosopher István Bibó has written about the 'national materialism' of the East-European countries, a state of mind which the Western Europeans cannot understand. It has grown out of the daily fight for mere survival. One citation: "One of the most characteristic features of the soul that has been tortured by fear and feelings of insecurity and major historical traumata and injuries is, that it does not want to make a living out of its own existence but it takes the position that it has a lot to demand from life, from history and from the others. In this state of mind the individual loses his sense of moral obligations and responsibilities towards the community. He uses every moral rule to prove his own demands ...."

This, I am afraid, brings us to what is happening in Yugoslavia, where people have reached a state of mind that Western Europeans cannot understand at all, and where the endless socalled peace conferences only seem to be a forum to repeat each party's demands on history. The IBM study contains data from a Yugoslav agent of IBM. This spring I went back to the data, which were collected in 1971, and split them into Slovenia, Croatia and Serbia; the company did not have sufficient employees in the other republics. The results are shown in this diagram, together with the scores for the highest and lowest EC country on each dimension.

POWER

DISTANCE
INDIVIDUAUSM

MASCULINITY

UNCERTAINTY GRE AVOIDANCE 112

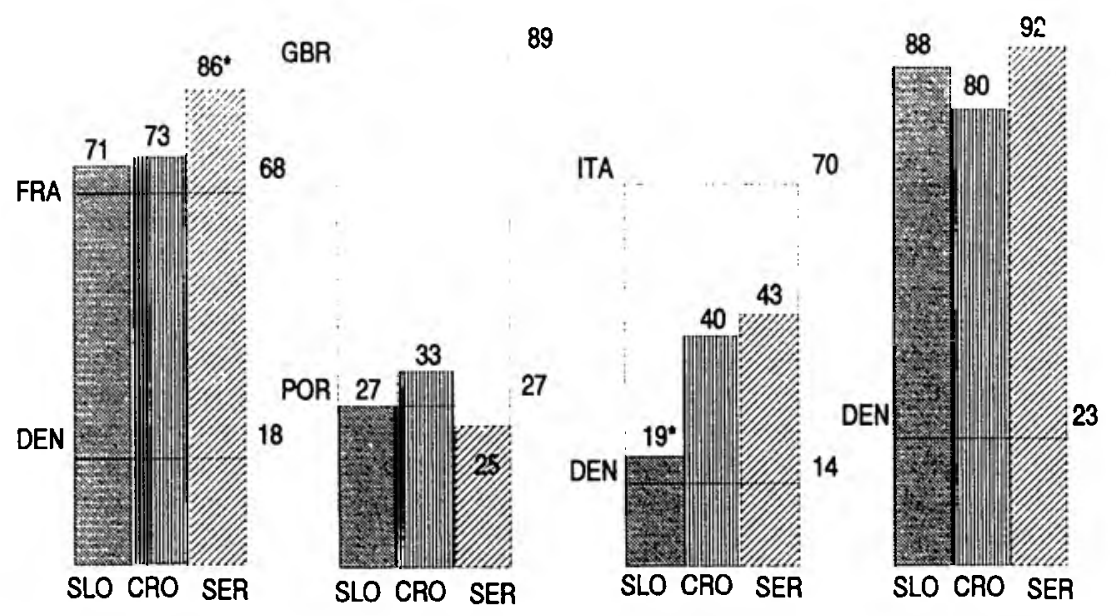

- significantly different from other 2 republics at .05 level

DEN $=$ Denmark, FRA $=$ France, GBR $=$ Great Britain, GRE $=$ Greeco, ITA $=$ Italy,

POR - Portugal ; SLO = Slovenia, CRO = Croatia, SER = Serbia

Scores for Yugoslav republics vs. EC countries in 1971 IBM data 
What strikes us first is the similarity among the three Yugoslav republics. In all three republics of the former Yugoslavia the 1971 scores showed large Power Distances, Collectivism, and strong Uncertainty Avoidance. Slovenia scored feminine, the other two republics medium on Masculinity. Serbia manifested a significantly larger Power Distance than the two other republics; it was also slightly more uncertainty-avoiding and Collectivist. Twenty years before Serbians started the Yugoslav civil war their compatriots within the IBM agency gave evidence of the state of mind conducive to explosive nationalism; and their two sister republics produced only slightly different answers.

The Serbian data from 1971 show a combination of large Power Distance plus strong Uncertainty Avoidance unequalled anywhere in my research in Europe. In 1988, before the breakdown of communism, my French co-author Daniel Bollinger administered the IBM questions to a group of engineers, more or less matched with the IBM employees, in Russia ${ }^{18}$. They produced scores for Power Distance and Uncertainty Avoidance almost equally high as the Serbs did. From the original IBM data the European country that comes closest is Greece.

About the only countries at present where the population sympathizes with the Serbians are Greece and Russia. It appears that the three share a common mental programming: it is the Latin pattern of large Power Distance plus strong Uncertainty Avoidance - like Hoppe found in France, Belgium and Italy - but taken to the extreme. With a sense of history we can identify it as a Byzantine pattern, the inheritance of the offspring of the Roman empire that lasted another thousand years in Byzantium after Rome fell, and that presently survives in Eastern Orthodox Christianity.

Greece and Russia score collectivist, but not as much as Serbia, which makes them less explosive. But signs of militant nationalist and racist currents in these two countries are regularly in our news. Such currents are a potential threat: to peace, especially if economic conditions deteriorate.

Regardless whether one considers free market capitalism desirable for Eastern Europe, one should face the fact that in most countries concerned the population's mental programming does not allow it. For the same reasons the poorer East-European countries will also have to do without democracy, at least for the foreseeable future, let us say the next fifty years or so. Democracy presumes at least a minimum level of individualism: "one man one vote" is an individualist principle. We also saw that individualism presupposes a minimum amount of wealth. Therefore democracy is for the wealthy or moderately wealthy countries only' ${ }^{19}$. This is unfair, but I can't change it. It is as unfair as the law of Jesus Christ according to Saint Matthew: "He who has, to him shall more be givenzo."

You may consider me a pessimist, or taking a static view of societies. I only try to be realistic. Mental programmes do change, but slowly and not according to anyone's master plan. Changes take decades, if not centuries. If the inheritance of the Roman Empire still separates Beigium from the Netherlands, two countries in intimate contact over two thousand years, one should not believe one can change the minds of Serbs, Russians or Albanians within a few years. In planning, we better take mental programs as given facts.

This lecture is coming to an end. I don't know whether you missed anything. I did not use the word culture one single time. I did this on purpose, of course. The word gets overworked: it has become too fashionable. Let us look at the real issues behind it. 


\section{Dear audience,}

In this same hall on 15th May, 1987 I gave my inaugural address with the title: "Gevolgen van het Nederlanderschap: gezondheid, recht en economie"; in the English language version:

"Dutch Culture's Consequences: Health, Law, and Economy". It addressed the three disciplines then taught at this university. At that time I dealt with the Netherlands; in tune with the times, this valedictory lecture extended its horizon to Europe. Consequently it could no longer be presented in Dutch, but it had to be formulated in Europe's new lingua franca. Euro-PidginEnglish.

In the past six years the widening of horizon reflected in my choice of topic has also affected this University. I cannot judge for other departments, but at least the department of Economics and Business Administration is in a process of profound change from a Dutch towards an international outlook. The department was founded in 1984; when I joined in 1985 its research and teaching foci: government, labour, and technology were mainly national, and the language used was Dutch. I have been an apostle of internationalization: I founded the programme in International Management, what is now known as IM. It included the requirement to take courses at one of the two neighbour universities, at Aachen or at Liège. The cooperation established for this purpose developed into the university-wide ALMA programme: Aachen, Liège, Maastricht.

Later on, internationalization even became part of the university's strategic plan, but institutions cannot be changed by decisions of governing bodies. Changing mentalities takes time: it is - let me use the word now - a matter of culture. The history of IM has shown this. I have studied cultural resistances in other organizations, but they still come as a shock when one experiences them in one's own environment. Yet I am confident that given some more time IM and the newly created programme of International Business, IB, will recover from earlier setbacks. Mentalities are changing.

The major force towards this change consists of the ERASMUS and related exchange programmes. In the academic year 1992-93 our department hosted 142 ERASMUS students from other European countries; via the university's Center for European Studies another 145 students from the U.S.A. and Japan took at least some courses from the department. These visitors forced existing faculty to widen their horizons and to improve their English, and they continue to affect the criteria applied in the hiring of new faculty.

From our Dutch student body also about 145 went abroad for at least part of the academic year 1992-93 studying at other European universities within the ERASMUS programme or one of its extensions; another 50 went abroad on internships with companies or other organizations; all of this in a department that in the past academic year graduated just about 200 students. This is a better number to compare with than the total number of enrolled students, because those who go abroad are usually close to graduation.

Watching returning students and listening to their stories, I believe that their culture shock and increased life experience represented even more valuable lessons than the academic subjects they took abroad. Let us hope that the European Commission will continue funding the ERASMUS programme for the coming years. Rarely has money been better spent for the future of European cooperation.

Pessimists today say that hoping for better European cooperation is folly. Desiderius Erasmus of Rotterdam, after whom the programme was named, is most famous for his essay "Praise of Folly", written in 1509. Erasmus started as a Dutchman and ended as a true European. 
He wrote "Praise of Folly" for his English friend Thomas More, and their German friend Hans Holbein spontaneously made illustrations for it.

Let us follow Erasmus in praising folly, the folly of expecting European countries to cooperate. Thank you for having come.

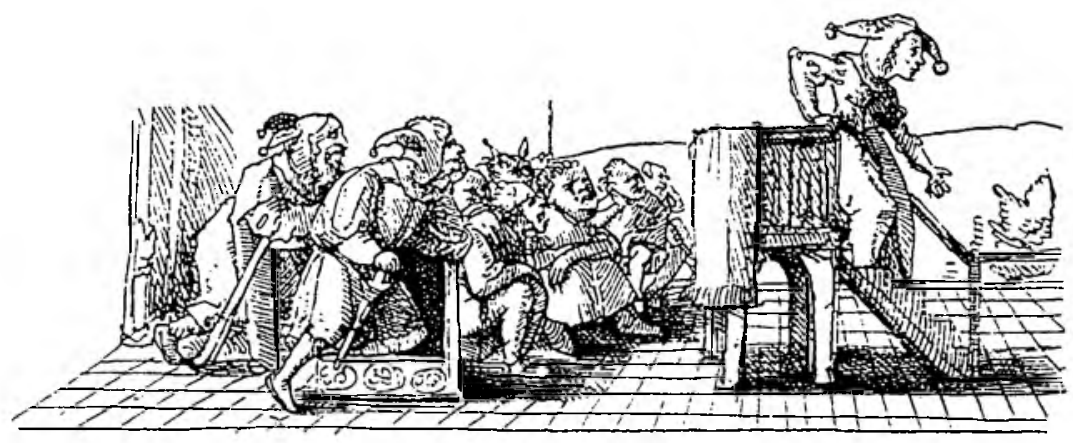

Sketch scribbled in the margin of his copy of "Praise of Folly", by Hans Holbein the younger. 


\section{Notes}

: The author thanks Maaike, Rokus and Bart Hofstede for comments on draft versions of this address; Johannes Putsch, Lilian ter Horst and Hans Holbein for their drawings; Philip Lincoln and Piet-Hein Veldman for making the diagrams, and Frank van Heusden for the references to Herodotus.

2 The Phoencian word ereb has the same root as the Arab word Maghreb which also means "The West". The similarity of the name to Europa, the beautiful princess abducted by god Zeus (who for the occasion had disguised himself as a bull) is therefore accidental, except that in the legend Europa was a Phoenician princess. Herodotus wrote: "As for Europe, nobody knows if it is surrounded by sea, or where it got its name from, or who gave it, unless we are to say that it came from Europa, the Tyrian woman, and before that was nameless like the rest. This, however, is unlikely; for Europa was an Asiatic and never visited the country which we now call Europe, but only sailed from Phoenicia to Crete and from Crete to Lycia." (Herodotus, The Histories, translated by Aubrey de Sélincourt and revised by A.R. Burn, Penguin Classics, 1972, Book Four, p. 285). Herodotus evidently didn't know Phoenician.

3 Herodotus commented: "Another thing that puzzles me is why three distinct women's names should have been given to what is really a single land-mass..." (The Histories, Book Four, p. 285).

"This is reflected in the results of recent research into the frequency distribution of human genes in Europe. See L.L. Cavalli-Sforza and A. Piazza, "Human genomic diversity in Europe: A summary of recent research and prospects for the future", in European Journal of Human Genetics, 1993, 1, pp. 3-18.

5 Rienk Prins, Sickness Absence in Belgium, Germany (FR) and the Netherlands: A Comparative Study. Ph.D. Dissertation University of Limburg, 1990.

6 World Development Report, 1992, Table 1. The figures are 77 years for the Netherlands versus 76 for Belgium and Germany.

7 Lynn Payer, Medicine and Culture: Notions of Health and Sickness in Britain, the U.S., France and West Germany. London: Victor Gollancz, 1989.

8 This, of course, has been inspired by a wonderful little book: Peter Berger and Thomas Luckmann, The Social Construction of Reality, Penguin Books, 1966. The title of this lecture "Images of Europe" was inspired by Gareth Morgan, Images of Organization, Newbury Park CA: Sage, 1986

9 Bourdieu's definition of habitus can be translated as "a system of permanent and transferable dispositions"; it "functions as the basis for practices and images... which can be collectively orchestrated without an actual conductor"; see Pierre Bourdieu, Le sens pratique, Paris: Éditions de Minuit, 1980, pp. 88-89; translations by $\mathrm{GH}$.

10 Geert Hofstede, Culture's Consequences: International Differences in Work-Related Values. Beverly Hills CA: Sage Publications, 1980; and Geert Hofstede, Cultures and Organizations: Software of the Mind. London: McGraw Hill UK, 1991.

11 Michael H. Hoppe, A Comparative Study of Country Elites: International Differences in Work-related Values and Learning and their Implications for Management Training and Development. Ph.D. Dissertation, School of Education, University of North Carolina at Chapel Hill, 1990. The quote is from p. 23. 
12 Britain, Germany, Netherlands, Poland and Sweden.

is René L. Olie, European Transnational Mergers. Ph.D. thesis University of Limburg. Forthcoming. 1994.

1.4 Hofstede, 1980, p. 173 and 178.

15 Emmanuel Todd, La troisieme planète: Structures familiales et systèmes idéologiques. Paris: Editions du Seuil, 1983. English transiation: The Explanation of Ideology: Family Structures and Social Systems. Oxford: Basil Blackwell, 1985.

16 Hofstede, 1991, pp. 75-76.

17 From Istvan Bibó, "The misery of the Eastern European small states", in Istvan Bibó, Selected Studies Vol. II, Budapest: Magvetô Publishing House, 1986, p. 238 (in Hungarian; originally published 1946). Quoted in Károly Varga, "Either Them, or Us": National Materialism in Central Eastern Europe, paper presented at the 6th annual conference on Conflict Management, Houthalen, Belgium, June 1993.

18 This study was part of a consulting project of CEGOS-Cooperation, Paris, France. The number of responses was 55, but not all were ethnic Russians; the group contained some Baltic and some Armenian members. The scores were Power Distance 93, Individualism 47. Masculinity - 1. Uncertainty Avoidance 75.

19 The reverse is not true: wealth is possible without democracy, as Singapore and Hong Kong show. 20 From the New Testament, Matthew 13:12. 